\title{
Socio-Cultural and Environmental Aspects on Toponymy System of Villages in the East Region of Cirebon
}

\author{
Amniar Ati, Bayu Iqbal Anshari, Eni Rosanti, Millary Agung Widiawaty and Moh. Dede \\ Universitas Pendidikan Indonesia, Jl. Setiabudhi no. 229, Bandung, Indonesia \\ amniar_ati@student.upi.edu
}

Keywords: Socio-cultural; The East Region of Cirebon, Toponyms.

\begin{abstract}
This research aims to reveal the origin and meaning of toponyms are contained on The East Region of Cirebon. The methods used in this study is ethnographic methods with descriptive qualitative approach and ethnolinguistic analysis technique. The object of this research is the name of villages in The East Region of Cirebon consisting of 191 villages from 18 sub-districts are located in the east of Cirebon Regency, West Java. Sources of data about names of villages in The East Region of Cirebon are obtained from literature studies and field observations. In this study found the physical environmental aspect on toponyms in The East Region of Cirebon means water, flora, landform, and land use. Meanwhile, socio-cultural aspects are characterized by words mean on historical events, expectations, perceptions, and community activities. Naming derived from Javanese (57\%), Sundanese (33\%), Sundanese and Javanese (8\%), and others language $(2 \%)$. Meanwhile, $42 \%$ of village toponim in the region means physical environment and $58 \%$ means sociocultural aspects.
\end{abstract}

\section{INTRODUCTION}

The East Region Cirebon is one of the presentment cultural acculturation in Indonesia, one of the affected entities is toponym. In Cirebon toponyms contained historical value that bring together Javanese and Sundanese culture to cause characteristic that only owned by Cirebon people (Anshari and Dede, 2016). It led to the claim that Cirebon is not Sundanese or Javanese which is indicated by the existence of the Cirebon Language Dictionary (Sujana, 19xx). Toponymy discussion deals with exploration the meaning of a region's name. Toponimi according to (Rais, 2008) that a geographical phenomenon of mountains, hills, rivers, headlands, valleys, islands and so named by humans in order to facilitate identification. In addition, the naming of a region also marks the various socio-cultural phenomena experienced by humans, such as the name karang, babakan and kampung which refers to the variant of the name of the settlement (Rais, 2008). Prior research was undertaken by Iventocsh (1964), Ashley (2000), Churchin (2008), Grillo (2015), and Kadmon (2004) who discussed the origin of names in the Ebro Valley, Himara District (Albania), Orinda California, Saints in Cornwall, and the name's influence on geopolitics. In addition, toponymy studies ever conducted in Indonesia by Ormeling (1984), and Perdana et al. (2015) discuss the need for pilots to master toponymy in Indonesia, and the origin of place names in Simalungun.

This research is a continuation of Anshari et. al. (2017) on toponymy Cirebon, all of the above studies show that studies in The East Region of Cirebon have not been studied. This research is expected to encourage the government to preserve the names mentioned in Undang-Undang No. 32 Tahun 2004 tentang Pemerintahan Daerah. In addition, it certainly adds toponymy literature in Indonesia and the world.

The point of view used in this study is ethnosemantic that is the exploration of the meaning of the word and cultural reflection in it. The purpose of this study is (1) explore the origins behind the naming of places in the eastern region of Cirebon; (2) classification of toponymy in The East Cirebon in according with socio-cultural and environmental aspects. To achieve this purpose required qualitative methods (Atieno, 2009) and combined with an ethnosemantic point of view. Therefore, the results seen are Java's dominant toponimi culture in The East Region of Cirebon. 


\section{LITERATURE REVIEW}

Toponymy as a source for historical reconstructions can thus pave the way for a proper understanding of (i) the topography of settlements as well as historical personages whose contribution to the establishment, development, and stability of such settlements is enormous, (ii) the location and distribution of various interest groups living in the settlements as well as other notable historical areas (Aleru and Alabi, 2010).

\section{RESEACRH METHODS}

As a qualitative research, the data collection effort on the toponym of The East Region of Cirebon is based on the empirical phenomenon of the speaker, so that the result of data obtained in the form of language provision skill. Then, the data is combined with the facts and socio-cultural facts and also environmental facts (Atieno, 2009). This research used human instrument with researcher-centered (Peredaryenko and Krauss, 2013). The data used by this research comes from documents of the names of villages and sub-districts in western Java. After that, a direct survey to the location of the research was then analyzed by the method of meaning and culture analysis that is ethnosemantic (Yelena, 2014; Fishcer, 2007).

By Using the study of language and culture, it is hoped that the discussion of toponym issues will remain at the level of meaning in disclosing the various relationships between language, culture, mind as well as patterns, conditions of society, and environment (Duranti, 1997; Kramsc, 2001). Thus, the people perception in eastern Cirebon will be revealed through toponymy in the area, by (1) Explore the origins behind the naming of places in The East Region of Cirebon; (2) classification of toponymy in The East Region of Cirebon in according with socio-cultural and environmental aspects.

\section{RESULTS AND DISCUSSIONS}

Administratively, Cirebon is divided into 45 subdistricts, where 40 sub-districts in Cirebon Regency and five sub-districts in Cirebon City. In this paper, Toponym study is located in The East Region of Cirebon consisting into 18 sub-districts with 191 villages. Region classification into the west or The East Region of Cirebon based on regionalization schema that region is an area shows certain characteristic and different from other area. The place characteristics be either physical, human or combined characteristics. The East Region of Cirebon is referred to physical aspect of the geographical position of its territory who located in the east of Cirebon City and Cirebon Regency (Contel, 2015).

The toponym specificity in The East Region of Cirebon when compared with others region in West Java is fusion influence from Sundanese, Javanese, and even other cultures such as Madurese or Dutch. It evidences 108 villages name in the region have come from Javanese culture. In addition, the influence of Sundanese culture can be found in 64 village. It proves Javanese culture domination (56.6 percent) on villages name in The East Region of Cirebon, due to historical phenomenon that Cirebon as a Mataram Sultanate logistical base under leadership of Sultan Agung on the operation to attack Batavia as VOC (Dutch East India Company) center between 16281629 AD (Ricklef, 2012)

\subsection{Physical Environmental Aspects}

Physical environment aspect include 80 villages from 191 villages in the region are registered in the Government of Cirebon Regency on 2017. From these, 27 names of villages are associated with plants (flora), 27 villages mean water, 2 villages mean soil, 2 villages associate with animals, 7 villages associate with landform, 3 villages mean natural land use, and 12 names are combination of various physical aspects. Classification about physical aspect on toponim according Sudas and Gokten (2012).

\subsubsection{Water}

The toponym mean river has traits by word kali (on Javanese) is mentioned 6 times, several villages such as Kalirahayu (Losari sub-district), Kalisari (Losari sub-district), Kalimeang (Karangsembung subdistrict, Kalipasung (Gebang sub-district), Kalibuntu (Pabedilan sub district), and Kalimukti (Pabedilan sub-district). Toponym kalimeang and kalipasung are given because the village is passed by Kali Gede stream. Then, Kalirahayu and Kalisari names based on environmental phenomenon that the villages were flow by river branch of Ci Sanggaraung. Meanwhile, Kalibuntu and Kalimukti names indicate $\mathrm{Ci}$ Benu stream who flow on the villages as a water source for agriculture (Sudas and Gokten, 2012). In addition, Kalimekar based on existence of a river who became as the boundary for Kalimekar dan Kalimaro. All villages are initiated by word kali, only Kalimeang 
whose the people not use Javanese as major language, but Sundanese.

Toponyms in The East Region of Cirebon which means river is found at several villages name in Sundanese, they characterized by word such $\mathrm{ci}$ or leuwi. $\mathrm{Ci}$ is used 10 times and only one for leuwi, such as Ciuyah and Cisaat (Waled Sub-district), the four village on Ciledug (wetan, kulon, tengah, and lor), Cipeujueh kulon and wetan (Lemahabang Subdistrict), Citemu (Mundu sub -district), and Cikancas (Beber sub-district). Interestingly, Cisaat and Ciuyah describes condition of river water are crosses the village as periodic river (saat mean dry) and salty (uyah mean salt). The field data shows moor (dry crops) is dominant landuse in Cisaat and Ciuyah. Then, Ciledug name appear from water quality of $\mathrm{Ci}$ Sanggarung, ci (river) and ledug (murky) show the murky water from material suspension as a part erosion processes (Núñez, et al., 2010).

Naming of Citemu villages is associates with river, $\mathrm{Ci}$ (river) and temu (meet) which mean estuary are given from hydrological phenomenon in the village, where some river streams are meet such as $\mathrm{Ci}$ Silopanganten, Kali Waruduwur, Ci Lelembu, and Ci Longkrang. Finnaly, Cikanscas toponym means clear water is given from the village position as large upstream area for Ci Kanci, Kali Kebonbuah, and Ci Kancas, so its normally if water flows in this village has best quality and quantity (Rajala, 2009). Word $c i$ as village toponym is also used in Cipeujeuh wetan and kulon, ci (water) peujeuh (sufficient) mean waterrich, its given due to physical condition as a productive agricultural area and flow by two river (Kali Putih and $\mathrm{Ci}$ Wadon), so the village rarely affected by drought.In The East Region of Cirebon there is also a village name whose associated with water. Leuwidinding village in Lemahabang subdistrict, leuwi (river) and dinding (wall) on sundanese has mean a river as boundary. The name is given from boundary of leuwidinding village with others is $\mathrm{Ci}$ Singaratu in eastern and $\mathrm{Ci}$ Singaraja in western. Toponyms meaning water are also found in three villages, namely Sumber Lor and Sumber Kidul (Babakan sub-district), and Tuk Karangsuwung (Lemahabang sub-district). The names mean springs location who cause people to build settlement.

\subsubsection{Plants}

Toponyms meaning plant in the East Cirebon region are divided into 6 names meaningful jati or teak, 5 names associated with gebang palm, 2 village using tamarind, 2 villages name beginning with $l o$ (goolar fig) and mundu (maphuut), and there is each one villages which meaning of putat, ambit, wareng, dukuh, widara, picung, kendal, beringin, waru, tanjung, and sembung. All plant in toponym according with environmental factor, such climate, soil, and altitude (Gholinejad et al., 2012). Thus, Plants on toponyms in the region are divided into 16 species.

\subsubsection{Landform}

Physical environment aspect is often contained in the toponym is landform (Derung and Purves, 2012). In The East Region of Cirebon, it is generally divided into two physiographic zones, the north lowlands and the southern hills. So, there are village name who explain several phenomenon as valleys, mountains or hills, coral reefs, sedimentary sediments, and waterfalls. In detail see tabel 1.

Tabel 1: Landform on toponyms.

\begin{tabular}{|c|c|c|}
\hline $\begin{array}{c}\text { Landform } \\
\text { origin }\end{array}$ & Information & Village Name \\
\hline Sedong & Valley or Canyon & $\begin{array}{c}\text { Sedong Kidul; } \\
\text { Sedong Lor }\end{array}$ \\
\hline Gunung dan \\
watu karang & $\begin{array}{c}\text { Mountain; Hills; } \\
\text { Karts Canonical }\end{array}$ & $\begin{array}{c}\text { Gunungsari; } \\
\text { Karangsari; } \\
\text { Karangmalang }\end{array}$ \\
\hline Bojong & Sediment material & Bojongnegara \\
\hline Curug & Waterfall & Curug \\
\hline
\end{tabular}

\subsubsection{Natural Landuse}

Natural land use categorize as natural form of land with all components inside which are not cultivated by humans. In The East Region of Cirebon, natural land use as toponyms consist of forest and swamp. If examined in detail, toponim of Luwung village (Mundu Sub-district) means the forest, it became due to Cirebon Sultanate's settlement expansion to the east. Whereas, Meanwhile, Rawaurip (Pangenan SubDsitrict) is derived from many tidal swamps are directly adjacent to sea, currently, it use as people's pond (Ormeling, 2013).

\subsubsection{Animal}

There are only two animals used as name of village in The East Region of Cirebon, namely milkfish and paper wasp. Milkfish (Chanos chanos) on Javanese called bandeng is a name for Bandengan village (Mundu Sub-district), it shows milkfish habitat in brackish water or saltwater (Nelson, 2006). This interpretation is also supported by the geographical position of Bandengan is located on sea side or 
estuary of Kali Grobogan and Ci Temu. Kamarang on Sundanese means paper wasp is often encountered in tropical rain forests. It name also based on wasp colonies are found during forest logged for settlement.

\subsubsection{Soil}

Area naming referring to soil (lemah on Javanese) condition in The East Region of Cirebon is found in Lemahabang sub-district, such as Lemahabang Kulon and Lemahabang Wetan. The name describes soil types are namely mediteran brown and grumosol as visually red (abang on Javanese) (Capra et al., 2015). In addition, In The East Region of Cirebon, there are some villages name who combine various meanings of physical environment such as plants and water, water and animals, land and vegetation forms, landforms and others (see table 2).

Tabel 2: Mixed physical environmental mean on toponyms.

\begin{tabular}{|c|c|c|}
\hline $\begin{array}{c}\text { Word } \\
\text { Origin }\end{array}$ & Information & Village Name \\
\hline $\begin{array}{c}\text { Mbeled } \\
\text { and } \text { asem }\end{array}$ & $\begin{array}{c}\text { Muddy soil (mbeled) } \\
\text { overgrown tamarind } \\
\text { (asem) }\end{array}$ & Waled \\
Asem \\
\hline $\begin{array}{c}\text { Jati } \text { and } \\
\text { pancuran }\end{array}$ & $\begin{array}{c}\text { Spring fountain } \\
\text { (pancur) near teak (jati) } \\
\text { vegetation }\end{array}$ & Jatipancur \\
\hline $\begin{array}{c}\text { Cai and } \\
\text { bogo }\end{array}$ & $\begin{array}{c}\text { River (cai) as striped } \\
\text { snakehead (bogo) } \\
\text { habitat }\end{array}$ & Cibogo \\
\hline $\begin{array}{c}\text { Leuweung } \\
\text { and gajah }\end{array}$ & $\begin{array}{c}\text { Forest (leuweung) as } \\
\text { elephant (gajah) habitat }\end{array}$ & $\begin{array}{c}\text { Leuweung- } \\
\text { gajah }\end{array}$ \\
\hline $\begin{array}{c}\text { Kamaran } \\
\text { g and } \\
\text { lebak }\end{array}$ & $\begin{array}{c}\text { Valley (lebak) } \\
\text { inhabited by wasps } \\
\text { (kamarang) }\end{array}$ & $\begin{array}{c}\text { Kamarang } \\
\text { lebak }\end{array}$ \\
\hline $\begin{array}{c}\text { Cai, awi, } \\
\text { and gajah }\end{array}$ & $\begin{array}{c}\text { River banks (cai) } \\
\text { overgrown with } \\
\text { bamboo(awi) and often } \\
\text { see elephants (gajah) }\end{array}$ & Ciawigajah \\
\hline $\begin{array}{c}\text { Bojong } \\
\text { and } \\
\text { gebang }\end{array}$ & $\begin{array}{c}\text { Gebang tree growth on } \\
\text { sediment material }\end{array}$ & $\begin{array}{c}\text { Bojonggeban } \\
\text { g }\end{array}$ \\
\hline
\end{tabular}

\subsection{Socio-Cultural Aspects}

Toponyms based on socio-cultural aspects are generally derived from various social phenomena who considered important in regional development. In The East Region of Cirebon, there are 21 village toponyms meaningful socio-cultural consisting of history, expectation, perception, artifacts, activities, irrigation, and others (Kleberen, 1983).

\subsubsection{Historical Means}

Perpetuation of historical events in the village toponym is doing to memorate any important events in early village establishment (Mutakin, 1999). In The East Region of Cirebon, historical events often involve various figures from royal family or some person have some advantages, such as the story of Prince Welang and Weling (Wilulang, Susukanbak sub-district), the eight (windu on Javanese) pilgrims (haji on Javanese) arrival (winduhaji, Sedong subdistrict), and Jaka Saliwah contemplation (Belawa, Sedong sub-district). In fact, tragic events of the Ki Ranggajati's death process was enshrined into three village names ie Gembongan (gembong mean body on Javanese), Gembongan Mekar, and Cangkuang (tied in a tree) which are located in Babakan subdistrict. Besides figure aspect who enshrine in the village toponym, Village establishing along with the pattern of settlement and iconic buildings are declared by the elders were also used as several villages name, such as Astanalanggar (grave beside the mosque) and Barisan (settlement with pararel patterns) in Losari sub-district, Banjarwangunan (Settlement line, Mundu Sub-district), and some villages are beginning with word babak (on Sundenese means start). In The East Region of Cirebon, there are many villages name indicating the presence of Cirebon sultanate facilities such as hunting (bedil) places (some village names in Pabedilan sub-district) and harbor (playangan on Javanese mean bunder). It reinforces some folklore who explains about some palace of the sultanate spread all over its territory.

Villages toponym of the east region Cirebon also often meaningfull struggle and success of village founder such as the Kudukeras (Babakan sub-district) and Durajaya (Greged sub-district) (Perdana et al., 2012). Another historical aspect that characterize several toponyms in The East Region of Cirebon is an event invites people to embrace Islam (da'wah) as in toponym of Kalimaro and Dompyong (Gebang Subdistrict), and Halimpu (Beber sub-district)

\subsubsection{Matter}

The toponym illustrates the public's disappointment into government (Dutch East Indies) policy is Nanggela (Greged sub-district). Nanggela origion from Javanese, nang means red onion and gela means disappointment, it is experienced by the community due to cultuurstelsel policy who requires farmers to grow sugar cane and forbidden to plant other commodities, including onion. Also, it is supported 
by easily access to sugar factories from the village in this region (Kleberen, 1983).

\subsubsection{Perception}

View or image of human to the surrounding environment can be used as name for a village, not least in The East Region of Cirebon (Kastanakis and Voyer, 2014). There are five villages toponyms are meaningful perceptions. Karangtengah is given by the community because it location between Karangswarung and Karangwareng villages. Then, toponim Karangsuwung means a quiet place, the two villages are located in karangsembung district. In addition, there are two villages have difficulty in accessing to the village at past, ie Wangkelang from wongilang (invisible person) explain a difficult accses for outer people (Lemahabang Sub-district), Karangwuni (unseen settlements), and Towangsari means settlement between paddies (Losari subdistrict).

\subsubsection{Artifisial Landuse}

Artificial land use is form of human composition in processing the surrounding environment to fulfilment life needs. In The East Region of Cirebon, artificial land use such as settlements are often used as villages name ie Karangmangun (Susukanbak sub-district) and Karangwangun (Babakan sub-district), they have similar meaningful about building settlements. Then, there are toponyms derived from agricultural land and people livelihoods namely Gagasari (Gebang subdistrict) meaningfull moor and Pasawahan (Susukanlebak sub-district) means rice fields (Ormeling, 2013).

\subsubsection{Irrigation}

The East Region of Cirebon is known as on of intesive agricultural center in West Java, no wonder if often meet irrigation infrastructure (Dede, et.al., 2016). Presence of agricultural infrastructures in The East Region of Cirebon could be used as villages name. For irrigation channels, there are several villages such as Kaligawe (on Javanese means artificial river), Susukanlebak (on Sundanese irrigation into the valley), Susukan Tonggoh (on Sundanese irrigation in the hills), and Susukanagung (on Sundanese large canal) in Susukanlebak subdistrict. In addition, there are several reservoirs for various purposes be an inspiration for village name, namely Setu Patok (Mundu sub-district) and Bendungan (Pangenan sub-district). Beside irrigation who correlated with agricultural activities, presence well is using as village toponym, namely Sumurkondang (Karangwareng sub-district) meaningful known wells and attracts residents to settle in the vicinity.

\subsubsection{Expectations}

When a village has been established, a good name is expected to affect the development of its people be civil society (Snyder, 2000). In The East Region of Cirebon, village toponyms based on hope or expectation of the village founders were divided into 5 categories, such as glory, honesty, welfare, achievement, and spirit. The glory is represented by toponym Mulyasari (on Javanese means keep the glory, at Losari sub-district), Sidamulya (on Javanese means become a glory, at Astanajapura sub-district), Astanamukti (on Javanese means Buried pleasures for noble, at Pangenan sub-district); Sampih (on Sundanese means keeping relation, at Susukanlebak sub- district), Karangwangi (on Javanese means glory village, Karangwareng subdistrict), Silihasih (on Sundanese means Mutual affectionate, Pabedilan sub-district); Pangenan (on Javanese means being miss, Pangenan sub-distric), and Suci (on Javanese means holy, Mundu Subdistrict).

Honesty also pinned as toponym for several villages in eastern Cirebon such as Astanajapura, Japura Lor, Japura Kidul, and Japura Bakti located in Astanajapura sub-district. Names of the village are meaningful for people to be honest with do Japura (aja pura-pura) or dont pretend. Beside honesty and glory, some villages in the region also used a inner and outer welfare as order to always surround for village naming, such as Kertawangun (build peace, Sedong sub-district), Mertapada Kulon and Wetan (affluent, Astanajapura sub-district), Tambelang (keeping enough, Karangsembung sub-district), and Sukadana (work lover, Babakan sub-district) (Snyder, 2000).

In the region there are many villages have meaningful expectations about achievement and spirit, such Sidaresmi (officially, Pabedilan subdistrict) Tersana (will be achieved, Pabedilan subdistrict), Sarajaya (free from evil, Lemahabang subdistrict), Gemulunglebak and Gemulungtonggoh (the best decision from pious persons, Greged subdistrict). Meanwhile, villages toponym are contain determination ie Greged (go, Greged sub-district), Buntet (spirit for useful, Astanajapura sub-district), Munjul (being superior, Astanajapura sub-district), Sinarrancang (spreading spirit, Mundu sub-district), 
and Windujaya (keep fighting, sedong sub-district) (Caldwell and Shine, 2008).

\subsubsection{Artefact}

Toponyms are mean artifacts or man-made objects in The East Region of Cirebon indicates on many villages like Panambangan (mean the ropes, Sedong sub-district), Sigong (mean gong, sub-district subdistrict), Kanci (mean the key, Astanajapura subdistrict), Ender (means kendher a kind of gamelan, Pangenan sub-district), and Beber (the shawl, Beber subdistrict). From some toponym are meaningful to artifatcs, there is a correlation between artifacts and figures of the Cirebon Sultanate (Ricklef, 2012).

\subsubsection{Activity}

Important matter can also be a name for a place. In The East Region of Cirebon, various toponyms are derived from people activities till now some of these activities are continue to one like occur in Pabuaran (Kastanakis and Voyer, 2014). More detail is shown in table 3. The naming of village based on human activity and on going until now only Pabuaran. It happens because geographic position of Pabuaran has located at the crossroads are connecting many growth centers such as Ciledug, Gebang, and Lemahabang. In addition, Pabuaran is the main access to Kuningan.

Tabel 3: Activities on toponyms.

\begin{tabular}{|c|c|c|}
\hline Word & Information & Village Name \\
\hline Ambu and gelu & Rest first & Ambulu \\
\hline Noong & Spy & $\begin{array}{c}\text { Panongan; Panongan } \\
\text { Lor }\end{array}$ \\
\hline $\begin{array}{l}\text { Cai and } \\
\text { Ngulak }\end{array}$ & Take a water & $\begin{array}{c}\text { Cikulak; Cikulak } \\
\text { Kidul } \\
\end{array}$ \\
\hline $\begin{array}{l}\text { Waled and } \\
\text { Desa }\end{array}$ & $\begin{array}{l}\text { Lively by native } \\
\text { citizens }\end{array}$ & Waled Desa \\
\hline $\begin{array}{l}\text { Waled and } \\
\text { Kota }\end{array}$ & Lively by chinese & Waled Kota \\
\hline $\begin{array}{l}\text { Paku and } \\
\text { Sambi }\end{array}$ & $\begin{array}{c}\text { Alternative } \\
\text { business place }\end{array}$ & Pakusamben \\
\hline Bubuara & Economic place & $\begin{array}{l}\text { Pabuaran Kidul; } \\
\text { Pabuaran Lor; } \\
\text { Pabuaran Wetan }\end{array}$ \\
\hline Tapa & Meditation & Patapan \\
\hline Penpen & Be alone & Penpen \\
\hline
\end{tabular}

Overall, toponyms distribution both physical environment and socio-cultural aspects shows a pattern, which is closer to the central of Cirebon Sultanate's impact on increasing amount of socio- cultural villages toponyms in The East Region of Cirebon (Sudas and Gokten, 2012), such as in Beber and Sedong sub-districts. Wherease, far distace from the center of the sultanate as in Pasaleman subdistrict, Karangwareng, and Ciledug are dominated by physical environment aspect. Another uniqueness in the region is direction word of Javanese language is dominant to show a geographic position for village, such wetan, kulon, kidul, and lor. In addition, Toponyms tendency derived from socio-cultural aspects of the region is also found in some villages are directly adjacent to the sea, it happens causes coastal areas is place for people of The East Region of Cirebon interaction with the outsiders, this condition further confirms that meaning of Cirebon is caruban or combination.

\section{CONCLUSION}

In language term, presence of toponyms in The East Region of Cirebon are dominated by origin names in Javanese $(57 \%)$, Sundanese $(33 \%)$, Sundanese and Javanese (8\%), and other languages. Whereas, form toponym's aspect there are $42 \%$ of villages meaningful to physical environment and $58 \%$ based on socio-cultural. In the region there also include a trend for distribution pattern of aspect toponyms which socio-cultural meaning tends to be near the center of the Cirebon Sultanate and along the coast. It is quite different from distribution of physical environment aspects are tend to inland and far from Cirebon Sultanate's infulence. Toponyms as part of intangible cultural heritage should be preserved like another national asset. The preservation through exploring and reinforcement of toponym meanings in The East Region of Cirebon and Indonesia as generally. It is necessary for the existence of location names is not just a name without meaning, but contains self and regional identity as a part of nation's cultural treasures.

\section{ACKNOWLEDGEMENT}

Thanks to Departmen of Indonesia Language and Literatture Education, UPI who held field observation in Cirebon. Also thanks to all informan in the East Cirebon. 


\section{REFERENCES}

Anshari, B. I., Dede, M., Tirtayasa, R., Tiryadi, Musthafa, K. 2017. Etnosemantic study on toponymy of Cirebon City and Regency. In Proceeding at Seminar Internasional Leksikologi dan Leksikografi 2017, 6469, Accesed on $9^{\text {th }}$ August 2017, from https://goo.gl/MxVxGD.

Anshari, B. I., Dede, M. 2017. Perception about ideal wife on tarling song Istri Apa Polisi by Yoyo Suwaryo'. In Proceeding at Seminar Internasional Riksa Bahasa X: Literasi dan Budaya Bangsa, 183-188, Accesed on 9th August 2017, from https://goo.gl/eErBei.

Ashley, L. R. N., 2000. The saints come marching in: saints' names in the toponymy of Cornwall. Names, 48(3-4), 257-264.

Bachtiar, T., 2008. Toponimi kota Bandung. Yayasan Purbatisti, Bandung

Caldwell, D. R., Shine, J. A. 2008. Homonyms in gazetteers: country-level duplicate names in the national geospatial-intelligence agency's geographic names data base. Coordinates, A(6): 1-21.

Capra, G. F., Ganga, A., Buondonno, A., Grilli, E., Gaviano, C., Vacca, S. 2015. Ethnopedology in the Study of Toponyms Connected to the Indigenous Knowledge on Soil Resource. PLoS ONE, 10 (3), e0120240.

Contel, F. B. 2015. Concepts of region and regionalization: aspectsof its evolution and possible uses to health regionalization, Saúde Soc. São Paulo, 24(2), 447-459.

Curchin, L. A. 2008. Place-names of the Ebro Valley: their linguistic origins. Palaeohispanica, 8(2008), 13-33.

Duranti, A. 1997. Linguistic anthropology, Cambridge University Press, Cambridge.

Dede, M., Sewu, R. S. B., Yutika, M., Ramadhan, F. 2016. Analisis potensi perekonomian sektor pertanian, kehutanan, dan perikanan serta pertambangan dan penggalian di pantura Jawa Barat', In Proceeding at Seminar Nasional Epicentrum 5.5, 100-108, at Dies Natalis Pendidikan Geografi FPIPS-UPI, Accesed on 9th August 2017, from https://goo.gl/JZihfn.

Derungs, C., Purves, R.S. 2012. Measuring topographic similarity of toponyms. In AGILE 2012 - Avignon Proceeding, April 24-27.

Gholinejad, B., Farajollahi, A., Pouzesh, H. 2012. Environmental factors affecting on distribution of plant communities in semi- arid area (Case study: Kamyaran rangelands, Iran). Annals of Biological Research, 3 (8): 3990-3993.

Grillo, H.. 2015. Toponymy as macrostructure and microstructure (study on the toponymy of the Himara district). In O. Felecan (ed.), Proceedings Of ICONN 3.

Iventosch, H., 1964, Orinda, California: or, the literary traces in California toponymy, Names, 12 (2), 103-107.

Kastanakis, M., Voyer, B. G. 2014. The effect of culture on perception and cognition: a conceptual framework. Journal of Business Research, 67 (4), 425-433.

Klaberen, J. 1983. The culture-system (Cultuurstelsel). In The Dutch Colonial System in the East Indies. Springer, Dordrecht
Kramsch, C. 2001. Language and culture, Oxford University Press, New York.

Mutakin, A. 1999. Suatu strategi dan implikasi pembelajaran nama tempat pada pembelajaran geografi. Jurusan Pendidikan Geografi FPIPS UPI, Bandung.

Nelson, J. S. 2006. Fishes of the world, Hoboken, John Wiley \& Sons: New Jersey.

Núñez, G. A., Briceño, M. I., Josephab, D. D., Asa, T. 2010. Colloidal coal in water suspensions. Energy \& Environmental Science, 2010 (5), 629-640.

Ormeling, F. J. 1984. The Pilot Training Course in Toponymy in Indonesia, Names, 32(4), 443-449.

Ormeling, F. 2013. "Residentiekaarten": the contents of the 19th century topographic maps of Java. In ICC Proceedings.

Perdana, A.P., Hendrayana, E., Santoso, W. E. 2012. THE important of toponym in the middle of maps and imagery for disaster management. In International Archives of the Photogrammetry, Remote Sensing and Spatial Information Sciences, Volume XXXIX-B4, 2012, XXII ISPRS Congress, 25 August - 01 September 2012, Melbourne, Australia.

Peredaryenko, M. S., Krauss, S. E. 2013. Calibrating the human instrument: understanding the interviewing experience of novice qualitative researchers. The Qualitative Report, 18 (43), 1-17.

Rais, J., et al., 2008. Toponimi Indonesia. Pradnya, Jakarta.

Rajala, H., 2009, .English place-names. INNERVATE Leading Undergraduate Work in English Studies, 2(2009-2010), 357-370.

Republic of Indonesia. 2004. Undang-Undang Republik Indonesia Nomor 32 Tahun 2004 tentang Pemerintahan Daerah, Kemendagri, Jakarta.

Ricklef, M. C., 2012. Sejarah Indonesia modern, Gadjah Mada University Press, Yogyakarta.

Saussure, F., 1959. Course of general linguistic. The Philosophical Library, Inc., New York.

Snyder, C. R. 2000. The past and future of hope. Journal of Social and Clinical Psychology, 19, $11-28$.

Sudjana, T. D. 2001. Kamus Bahasa Cirebon, Humaniora Utama Press, Bandung. 